\title{
Blackrocks: Craft Brewing - From Hobby To Business: Applying Strategic Management To The Small Firm
}

Brian Gnauck, Northern Michigan University, USA

Claudia Hart, Northern Michigan University, USA

Larry Pagel, Northern Michigan University, USA

\begin{abstract}
Blackrocks, a craft beer start-up company, first opened in Marquette, Michigan, a town of 20,000 residents, in 2010. The business evolved around a friendship and a mutual interest in craft beer and is located in Marquette's "Village," an area close to the local university consisting of several full-service restaurants, sandwich shops, bars, and retail shops. The Village considers itself an independent retail section of Marquette.
\end{abstract}

The ambience of Blackrocks is "fun and good times." People of all ages are attracted to the bar to enjoy craft beer with their family and friends. The physical setting is rustic with a current capacity of 50 customers (soon to expand to 100 customers). Customers can bring in their own food or call a local eatery for pizza or sandwich delivery.

Blackrocks has a very loose organizational structure which has worked well in the past. This case will allow students to identify the problems faced by Blackrocks in today's economy; to describe the internal and external environment of Blackrocks; to identify their core competencies; to identify Blackrocks' strengths, weaknesses, opportunities, and threats; and to develop management strategies which could further enhance the business and help them attain their mission and goals.

Keywords: Craft Beer; Organizational Strategies; Organizational Structure; External Environment; Internal Environment; Core Competencies; Management Strategy

\section{INTRODUCTION}

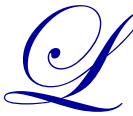

et's meet the employees of Blackrocks. The owners, the Ambassador of Fermentology and Brewsician Andy Langlois and David Manson were two, but there were also characters like the Wizard of Ales, the Monk of LaMash, the Gangster of the Great White North, and the Friend of Woodland Creatures Everywhere (the longest name of any employee in the business).

Blackrocks, the company, liked to enjoy life, have fun, and at the same time make money. The general attitude the business presented was pure Adam Smith "laissez faire," anything goes. Formal titles were few, but fun titles abound. At the same time, it was a real business with concern about sales, cost controls, growth, and serving customer needs.

Andy and David expressed concerns about the future demand for craft beer and beer in general. Craft beer in the U.S. represented 7.5 percent of beer by volume and 9.1 percent by revenue. Would the demand for craft beer crash or begin to fall off? (Remember, the demand for pop in the U.S. declined in the last 10 years.) Would the overall interest in craft beer begin to wane? These were unknowns. They also expressed concern whether the demand for onsite beer would decline. Should they develop bottled beer for resale through wholesalers to retail 
outlets? The policy of Blackrocks had been to stress variety. Each week new and different flavors of beer were created. Since opening in December 2010, they brewed over 150 different beers. Some beer rotated on a semiregular basis, but the majority was new every week. They had not established a "brand" that represented the brewer, "Blackrocks."

Samuel Adams, for example, had created "Samuel Adams Boston Lager," which supported a variety of other beer. Could Blackrocks create a brand that would sell over the counter? Did they need a beer that represented the brewer, "Blackrocks"? Was their business model sound? What issues should Andy and David focus on? Answers to these and other questions were constantly on their minds.

\section{THE ORIGIN}

Blackrocks started in December 2010 in Marquette, Michigan, a town of 20,000 residents, which expanded by 50 percent when the students of Northern Michigan University arrived each fall. The business was the brain child of Langlois and Manson.

Both men were in their 40's and faced the typical challenges of family life. Andy was married with two kids. He was a Northern Michigan University graduate. His previous work included Director of Sales for a surgical parts company and a drug representative. David was a Michigan State University graduate and worked for a Midwest food distribution company and also as a pharmaceutical sales representative for 16 years. Their wives worked - one was a school teacher and the other was a government manager.

The business evolved around a friendship and a mutual interest (avocation) of craft beer. This hobby grew into the idea of a business, and in 2010 they opened to the public in an old, private residence (zoned business by 2010) at 424 N. Third Street in Marquette, Michigan (see Figure 1). They were able to buy the building, giving up a small interest in their business.

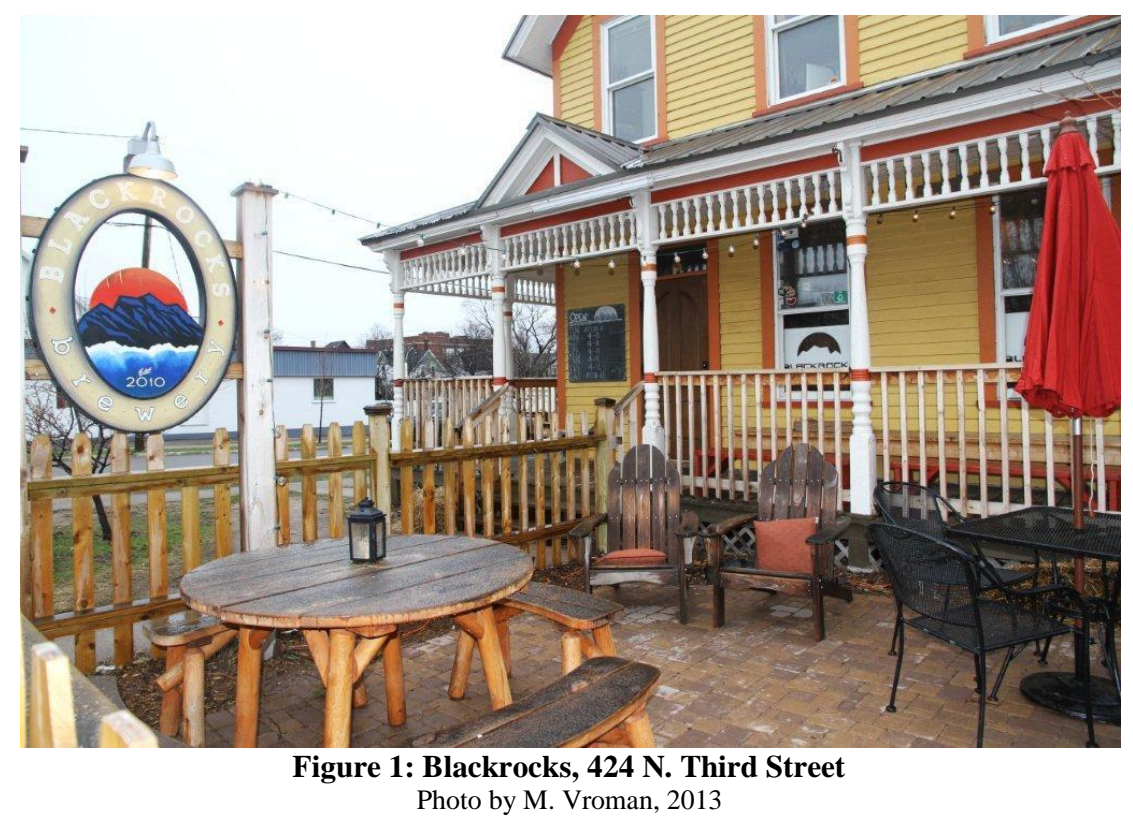

Third Street in Marquette, Michigan, was called "The Village" and consisted of a number of full-service restaurants, sandwich shops, bars, and unrelated retail outlets. The Village promoted itself as an independent retail section of town. It was a natural corridor of 13 blocks leading south from the university to the "Main" Street of the town. 
Given that Marquette was a university town, it was common for students to start a night celebrating by moving from bar to bar along Third Street. In this context, Blackrocks was a flow-through site as the customers moved north or south along this street. In simple terms, it was a great location for a craft beer business.

The ambience of Blackrocks was "fun and good times." Its physical setting was rustic. The hardwood oak floors creaked, as did the stairs to the second floor. The bar was an old, aged-oak structure that had seen extensive use by customers and lots of spilled beer (see Figure 2). In the spring of 2013, Andy and David planned to renovate the second floor to accommodate an additional 50 people. When finished, the legal capacity was 100 people $(1,200$ sq. ft.). There was a porch around the building which served as overflow when temperatures reached over 40 degrees (outdoor heat lamps were prevalent) and in the summer and fall periods. Seating capacity was limited to about 15 so the rest of the patrons stood.

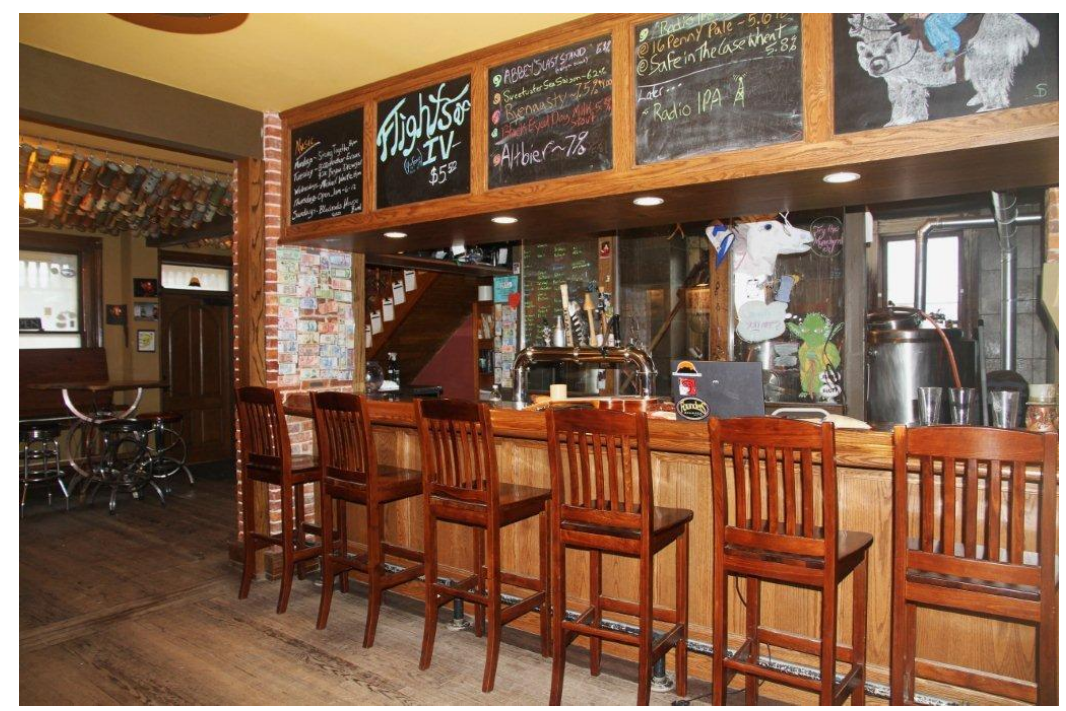

Figure 2: Blackrocks Bar

Photo by M. Vroman, 2013

The fun-loving, informal atmosphere was even more evident by patrons carrying in their own food or calling local eateries for pizza or sandwich delivery. Crowded tables and benches were often filled with crock pots full of soup, appetizers, or other favorite accompaniments. Blackrocks did not have a kitchen so food regulation was not an issue. A night at Blackrocks was characterized by a high decibel rating and lots of conversation and laughter. Local musicians frequently entertained and open mic nights were common.

\section{TARGET MARKET}

Blackrocks targeted patrons of all ages. Lots of $21^{\text {st }}$ birthday parties occurred, but the brewery attracted people in their 30's, 40's, 50's, and 60's, as well as an occasional 90 year-old. It was not uncommon to see a 21 year-old sitting next to a surgeon with a university professor as part of a conversation.

\section{THE MUGS}

Shortly after opening, a friend and an art teacher at NMU suggested Blackrocks try to promote interest in German ceramic beer mugs. These mugs were all unique and fit the fun, rustic ambience of Blackrocks (see Figure 3 ). The mugs cost the customer $\$ 40$, but they brought the customer to the business. They hung on the walls, ceiling, and just about everywhere at the bar. Customers came in the door, grabbed their mug and had it filled at the bar. The mugs were truly works of art. In the course of $2 \frac{1}{2}$ years, they sold 986 mugs. A side benefit to Blackrocks was that the company did not have to invest in as many glass mugs because the customers supplied their own. The mugs also accommodated the rustic nature of the building and enhanced the "fun and good times" ambience. 


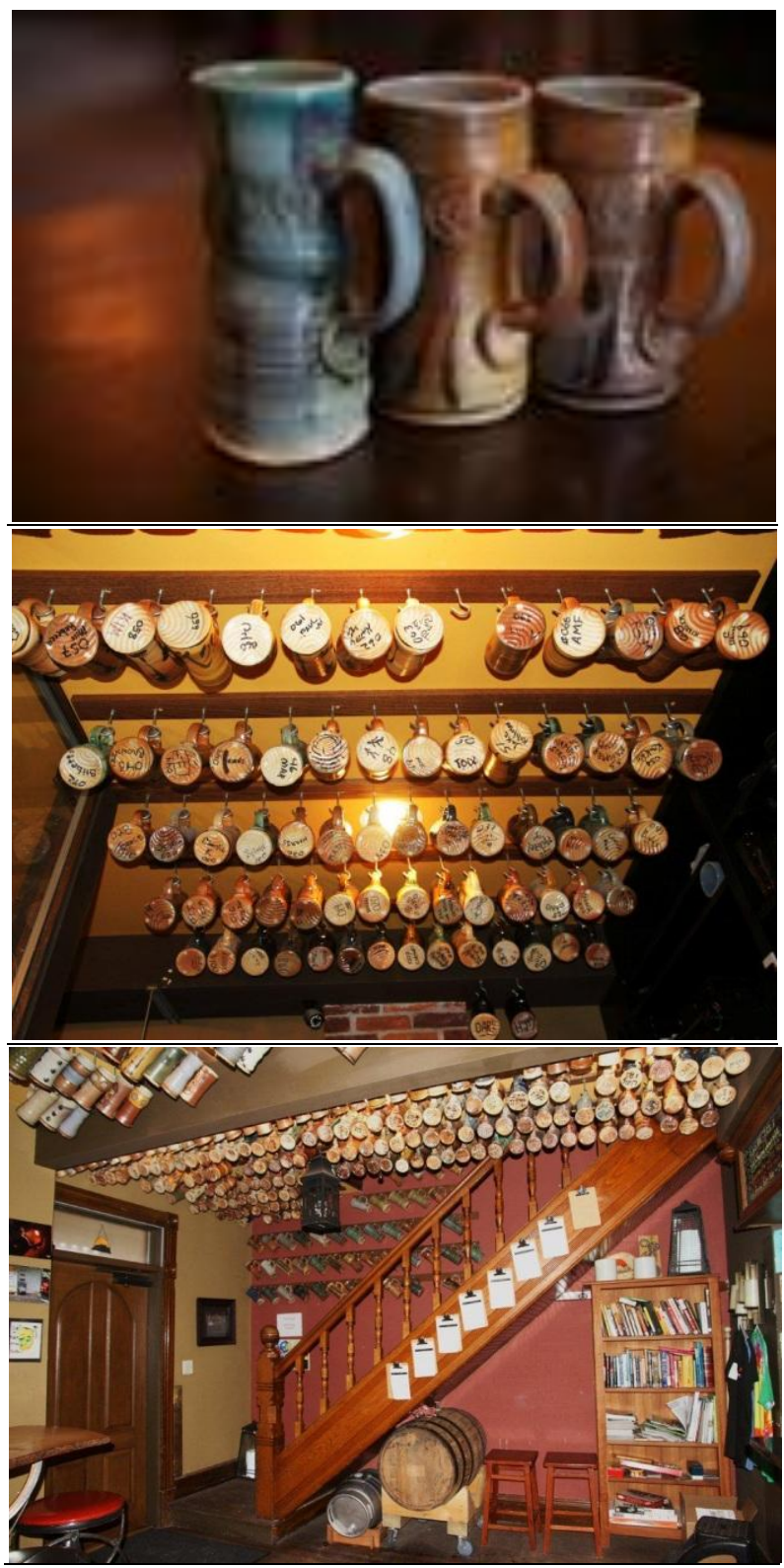

Figure 3: The Mugs of Blackrocks Photos by M. Vroman, 2013

\section{THE MISSION}

Even though the environment was one of fun and laughter, there was a serious side to the business. Andy and David established their "mission" as an integral part of what their business stood for when they created it in 2010 (see Figure 4).

Blackrocks is committed to fun, our community and diverse craft beer. We started as a nano brewery and will operate as such always. Our goal is steady growth brewing with quality ingredients and keeping a little crazy in our culture. We encourage our members, employees, and customers to give input in our operations and demand they know the brewing process and encourage mistakes.

\section{Figure 4: Blackrocks Mission}

Source: Company Records, 2013 
This mission tied the product to the customer and helped define what Blackrocks was all about - a happy, fun place to be and a mutual interest (proprietor - customer) in craft beer.

\section{ORGANIZATIONAL STRUCTURE}

The easiest way to explain Blackrocks' structure was to say there was none. Andy and David were the owners (the former building owner had a small interest). There were four full-time employees of the company. Besides the owners, the following is a description of the two other full-time employees, Andrew Reeves and Chris Hutte.

Andrew Reeves: Andrew was the head brewer. He was a 27 year-old having grown up in Holland, Michigan, and then worked for AmeriCorps in Colorado where he was exposed to the craft beer business. He then attended Northern Michigan University majoring in history.

Chris Hutte: Chris earned a Computer Information Systems degree from Northern Michigan University. He had been a part-time worker at a local party store that sold home hobby craft beer supplies and equipment.

There were seven part-time employees of the business. These people were brewers, bartenders, servers, keg cleaners and took on marketing responsibilities.

The organizational structure was flat with two levels of management. Andy and David were co-owners, and the rest reported to them in somewhat of an undefined, unknown manner. Things seemed to get done, however. To a degree, beer was brewed on schedule to make sure sufficient supplies were available when the business was open, supplies were ordered (barley, hops, wheat, rye, oats, nutella, lavender, honey, and peppers), and hours were assigned for work shifts.

\section{THE 2013 ECONOMY}

The Wall Street Journal reported that the $4^{\text {th }}$ quarter gross domestic product of the U.S. in 2012 was revised upward from a -.1 percent growth to a +.1 percent growth in January 2013. At the federal level, the U.S. House of Representatives was in an ongoing stalemate with the U.S. Senate and the President regarding spending cuts and tax increases. Unemployment stood at 7.7 percent, and interest rates were at historic lows. The federal funds rate was 0 to .25 percent, while the home mortgage rate for top-line borrowers was 3.25 percent for a 30 -year mortgage.

The State of Michigan had recovered from its depressed state with a balanced budget and 8.8 percent level of unemployment ("Department of Numbers," 2013). The Upper Peninsula of Michigan was somewhat depressed with an unemployment rate of 10.3 percent (Walton, 2013). However, the City of Marquette, the largest city in the Upper Peninsula of Michigan, was rather robust. This was because of Marquette General Hospital's 2,000 employees and 200 physicians (a for-profit hospital, part of the Duke Lifepoint System), Northern Michigan University's 1,000 employees (student body of 9,500 students), gambling in the Upper Peninsula which employed about 1,500 in the Central Upper Peninsula, and Cliffs Natural Resources' 1,800 employees (an iron ore mining complex located 40 miles west of Marquette).

\section{THE BEER BREWING PROCESS}

Brewing the beer began with the raw grain, which was most commonly malted barley for most beer styles. Other raw materials were wheat, rye, and oats, which could be added at different proportions for various beer styles.

The malted barley was first crushed to break open the hulls. This was then mixed with hot water (roughly 145-158 degrees) to create the "mash." During the mash, two enzymes (alpha and beta) worked to break down complex carbohydrate chains into simple sugars within the grain. This was important because yeast needed simple sugars to convert to alcohol later in the fermentation process. 
Mashing usually lasted for 60-90 minutes, then the liquid (called the "wort") was transferred to the boil kettle, and the spent grain was disposed of. The wort was then boiled for 60-90 minutes. During the boil, hops were added to balance the beer and provide bitterness and hop flavor/aroma. Hops added during the beginning of the boil were called "bittering" additions since the longer hops were boiled, the more bitterness they provided to the beer. Hops added at the end of the boil were called "aroma" additions because these provided hop flavor and aroma without as much bitterness.

Once the boil was completed, the wort was cooled and transferred to a fermentation tank. This was essentially the end of the first step.

Step 2 was the fermentation process. Once yeast was added to the cooled wort, sugars were metabolized into alcohol and carbon dioxide, and the product can be called beer for the first time. This process usually took 1-2 weeks. The style of beer and strain of beer affected how long fermentation took. This was an incredibly interesting process and had a lot of factors that affected the end beer product. It essentially came down to yeast converting sugar to alcohol, thus creating beer.

Once fermentation was finished, beer was transferred into what was called a "brite" tank. This was where the beer became carbonated. $\mathrm{CO}_{2}$ was applied to the beer until a desirable level of carbonation was achieved. The carbonation process took about 12 hours on average in a brite tank. Then the beer was transferred into kegs, cooled, and made ready to be served.

\section{BREWING AT BLACKROCKS}

Blackrocks had about a 600-barrel beer capacity per year. Their major competition, the Vierling and Ore Dock, had approximately 350- and 1200-barrel capacity, respectively. In the spring of 2013, Blackrocks bought an old Coca-Cola bottling plant on Washington Street, about a mile from the Blackrocks retail outlet, with the prospect of producing a bottled craft beer.

\section{COMPETITION}

From a broad perspective, craft beer was in competition with all beer; but in reality, craft beer like that made at Blackrocks was in competition with two other craft brewers in the city - the Vierling and the Ore Dock. In the general area, Jasper Ridge Brewery in Ishpeming, Michigan, a city about 15 miles west of Marquette, represented nearby competition. Also, KBC in Houghton (90 miles north) was, to a degree, a competitor. They sold craft bottled beer that was distributed in the area. Indirectly, Blackrocks also competed with the largest craft beer company in the nation, Samuel Adams. According to Jim Kock in an interview with Eng (2013), there were about 2,400 microbrewers in the United States as of January 2013. Rolling Rock, Ambersteam, Killian's Red, and Honey Brown were some of the products produced. Literally, tens of thousands of other national, regional, and local specialty beer were a form of competition. The interesting thing about these beers was that they had established followers and were known brands of their respective brewers. 


\section{FINANCIALS}

Blackrocks Income Statement and Balance Sheet for 2012 appear in Figures 5 and 6.

\section{Blackrocks Brewery Income Statement}

January 1, 2012 - December 31, 2012

$\underline{\text { Percent of Net Sales }}$

\begin{tabular}{lrr} 
Sales (net) & $\$ 328,906.26$ & $100 \%$ \\
Cost of Goods Sold & $\$ \quad 85,491.55$ & $26 \%$ \\
Gross Profit & $\$ 243,414.71$ & $74 \%$ \\
Total Expense & $\$ 195,037.99$ \\
Net Ordinary Income & $\$ 48,376.72$ \\
Net Other Income & $\$ \quad 529.77$ & \\
Net Income & $\$ \quad 48,906.49$ \\
\hline
\end{tabular}

Figure 5: Blackrocks Brewery Income Statement

Source: Company Records, 2012

\begin{tabular}{|c|c|}
\hline & $\begin{array}{c}\text { Blackrocks Brewery Balance Sheet } \\
\text { 31 December } 2012\end{array}$ \\
\hline $\begin{array}{l}\text { Assets } \\
\text { Current Assets } \\
\text { Fixed Assets } \\
\text { Total Assets }\end{array}$ & $\begin{array}{rr}\$ & 6,790.58 \\
\$ & 253,422.05 \\
\$ & 260,212.63 \\
\end{array}$ \\
\hline $\begin{array}{l}\text { Liabilities } \\
\text { Current Liabilities } \\
\text { Long-term Liabilities } \\
\text { Total Liabilities }\end{array}$ & $\begin{array}{lr}\$ & 17,594.05 \\
\$ & 92,654.11 \\
\$ & 110,248.16\end{array}$ \\
\hline $\begin{array}{l}\text { Equity } \\
\text { Total Liabilities \& Equity }\end{array}$ & $\begin{array}{ll}\$ & 149,964.47 \\
\quad 260,212.63 \\
\end{array}$ \\
\hline
\end{tabular}

Figure 6: Blackrocks Brewery Balance Sheet

Source: Company Records, 2012

\section{GENERAL INFORMATION}

Blackrocks did not advertise except for one ad in Brewers Guild when they first started business. They did, however, get lots of word of mouth, Facebook, and Twitter activity. General labor was relatively inexpensive in the $\$ 10$ to $\$ 12$ per hour range. Their brewers were all self-taught. They did not hold any certifications; but together, the brewers had 20-25 years of home brewing experience. David believed that some formal schooling would add knowledge to their brewing activity and should be considered in the future.

From a regulatory point of view, Blackrocks had to purchase a $\$ 50$ license from the State of Michigan and a Brewer's Notice (bond) of $\$ 1,000$ from the Feds. They also faced access, parking, and sanitary requirements of the county and city.

Entry into this type of business was not significant. For $\$ 100$, one could get into the hobby of beer making and for about $\$ 170,000$, get capacity up to 600 barrels per year, the volume Blackrocks produced as of February 2013. 
Hops were purchased through a contract with a farmer in the Rock, Michigan, area. All other ingredient prices were set by commodity markets (many items had world prices). David expressed some concern about this since many grains were at all-time high prices.

The primary substitutes for beer were hard liquor, wine, and wine coolers. However, these markets were somewhat separated. There were overlaps, but many consumers of wine, for example, did not consume beer (to any extent) and visa-versa. But alcohol and its effects on the human body were present in all, and all were in demand and replaced each other in a given setting.

Fun and good times were a significant part of what Blackrocks stood for. The pumpkin carving event was typical of the environment Blackrocks tried to promote. One of the part-time employees had a few pumpkins brought in during Halloween, and in no time everyone in the bar was drinking beer and carving pumpkins. The competition was fierce and the camaraderie was significant. The Blackrocks' atmosphere truly represented how Andy and David described their business, "art mixed with science - it is creative, like jazz mixed with symphony."

Andy and David were excited about their upcoming remodeling and the doubling of their business capacity. However, they had to make some important decisions to secure the future of their business. They knew what they had to do was their responsibility.

This case was prepared by Brian Gnauck, Claudia Hart and Larry Pagel of Northern Michigan University and is intended to be used as a basis for class discussion rather than to illustrate either effective or ineffective handling of a business situation.

\section{AUTHOR INFORMATION}

Brian Gnauck is a professor of management at Northern Michigan University. He returned to the classroom in 2000 after serving 15 years as Dean of the Walker L. Cisler College of Business. He has been on the faculty of the college since 1972. Prior to that he was assistant professor of logistic management at the School of Systems \& Logistics at the Air Force Institute of Technology, Wright Patterson AFB, Ohio. The school offered a master degree in logistics management to U.S. Air Force officers and officers of allied nations of the United States. E-mail: gnauck@nmu.edu

Claudia Hart is a professor of management at Northern Michigan University. She has been on the faculty of the college since 1981 and earned her Ph.D. from the University of Minnesota in 1988. She teaches in the area of managerial communication and training and development both at the undergraduate and graduate levels. Her research interests include active learning in the university classroom, conducting communication audits in organizations, and improving communication and teamwork through understanding personality profiles. E-mail: clhart@nmu.edu (Corresponding author)

Larry Pagel is a professor of business education at Northern Michigan University. He has been on the faculty of the college since 1997 and earned his Ph.D. from the University of North Dakota in 1986. Prior to that he taught at St. Cloud State University and the University of Wisconsin-Whitewater. He teaches primarily in the area of communication. E-mail: lpagel@nmu.edu

\section{REFERENCES}

1. David, F. (2004). Strategic management. Upper Saddle River, NJ: Prentice Hall.

2. Department of Numbers. Michigan Unemployment. Retrieved October 4, 2013 from http://www.deptofnumbers.com/unemployment/michigan/

3. $\quad$ Eng, D. (2013, Apr 08). Samuel Adams's beer revolutionary. Fortune, 167(5), 26.

4. Hill, C., \& Jones, G. (2007). Strategic management. New York: Houghton-Mifflin.

5. Hitt, M., Ireland, R., \& Hoskisson, R. (2001). Strategic management competitiveness and globalization. Mason, OH: South-Western. 
6. Mariott, S., \& Glackin, C. (2010). Entrepreneurship: Starting and operating a small business. Upper Saddle River, NJ: Prentice Hall.

7. $\quad$ Pearce, J., \& Robinson, R. (2012). Strategic management. New York: McGraw-Hill.

8. Porter, M. E. (1979, March). How competitive forces shape strategy. Harvard Business Review, 57(2), 6.

9. Prahalad, C. K., \& Hamel, G. (1990, May). The core competence of the corporation. Harvard Business Review, 68 (3), 2-15.

10. Walton, N. (2013). February unemployment in U.P. up a tad. Retrieved April 10, 2013 from the Public Radio 90 WNMU-FM website: http://wnmufm.org/term/upper-peninsula-unemployment

11. Weihrich, H. (1982). The TOWS matrix: A tool for situational analysis. Long Range Planning, 15(2), 61. 


\section{TEACHING NOTE}

\section{Case Overview}

Two longtime friends, Andy Langlois and David Manson, had a passion for making craft beer. After working for about 18 years in the private sector, they started a retail craft beer "pub" in Marquette, Michigan. The first $2 \frac{1}{2}$ years went well. They were on their way to forming a viable business when they started to express some concerns and posed some management questions about their business.

Would the demand for beer and "craft beer" keep expanding? Should they develop a craft "brand" for bottling and sell it for outside consumption? How could they better balance production with consumption?

They had developed a very "loose" organizational structure which seemed to work well given their size. But would it be okay if they grew? Answers to these questions and the kind, timing, and nature of the decisions Andy and David made at this stage of their business were important to their future success.

\section{Data Collection}

In February 2013, Drs. Gnauck, Hart, and Pagel interviewed Andy Langlois, David Manson, and Steve Farr (a part-time employee) of Blackrocks at their retail outlet in Marquette, Michigan. Additional phone and e-mail communication gained further information and data for the case.

\section{Learning Objectives}

After analyzing this case, the students will be able to:

1) Identify the primary problems facing Blackrocks as of 2013.

2) Describe the external environment of Blackrocks.

3) Describe the internal environment of Blackrocks.

4) Identify Blackrocks' capabilities and core competencies.

5) Identify Blackrocks' strengths, weaknesses, opportunities, and threats.

6) Develop specific management strategies which would further enhance the business and help them attain their mission and goals.

\section{Suggestions for Classroom Use}

This case focused on the application of strategic management to a small business retail LLC. Blackrocks had sales of $\$ 328,906$ in 2012. Students will be able to employ the basic concepts of strategic management to tackle the problems facing Blackrocks. By logically following the strategic management process, appropriate direction can be provided to this small business enterprise. Thus, this case is best suited in an undergraduate strategic management class or a small business management class.

This teaching note focuses on ideas from Hitt, Ireland, and Hoskisson (2001), David (2004), and Pearce \& Robinson (2012). Given the small business and non-sophisticated nature of the business, students get engaged in the case quickly. Since the case's business model is not complex (selling craft beer at retail), students understand it quickly and can focus on the problems facing the company.

The case demonstrated the need to prioritize problems and make good decisions.

Questions (Actions) and Question Answers

1. What were the primary problems facing Andy and David (Blackrocks) as of February 2013?

The business faced a number of problems that should be addressed to provide a solid foundation for future success. 
1. A need to create a formal organizational structure for the business.

2. A need to create general job descriptions for all employees, part- and full-time.

3. Answer to the question, "Should they produce and bottle a beer for outside sales and wholesale it?"

4. The value of an advisory board (board of directors).

5. The role and value of staff and management development.

6. A plan for growth and a need for Andy and David to spend more time planning.

2. How can Andy and David develop specific strategies to deal with these 6 areas? Employ the strategic management process. In order to accomplish this, four subordinate questions need to be answered.

a. What is (describe) the external environment of the firm? Pearce and Robinson (2012) include the following when describing the external environment:

\author{
Remote Environment (Global and Domestic): \\ *Economic \\ *Social \\ *Technological \\ *Demographic \\ *Political/Legal \\ Industry Environment (Global and Domestic): \\ *Entry Barriers \\ *Supplier Power \\ * Buyer Power \\ *Substitute Availability \\ *Competitive Rivalry \\ *Complementors \\ Operating Environment (Global and Domestic): \\ *Competitors \\ *Creditors \\ *Customers \\ *Labor \\ *Suppliers
}

Blackrocks' remote environment can be described as follows:

Economic: The economy of the local community was robust. Marquette, Michigan was an island of relative prosperity in a sea of decline. The City of Marquette and its immediate surroundings with the hospital (employment of about 2,000 and 200 physicians), the university (employment of about 1,000 and 9,500 students), the mines (employment of about 1,800), and gambling (employment of about 1,500) all supported an economy that represented higher incomes and enhanced discretionary spending. Aspects of the national economy were also relatively robust. The stock market hit an all-time high in September 2013. Even though the State of Michigan's unemployment rate and that of the Upper Peninsula of Michigan were high, the local Marquette communities' environment was solid for craft beer as of February 2013.

Social: Students were, and will always be, attracted to alcohol beverages in general and beer specifically. A university town always has a demand for entertainment. University students seek out excitement and good times. Also, craft beer had expanded in the marketplace over the last 15 years. Craft beer represented about 9.1 percent of total beer revenue as of 2013.

Technological: Beer making had not changed much since it was first invented thousands of years ago. Yes, the big brewers all had significant technology, but the small craft brewers largely followed the traditional process. 
Demographic: Blackrocks targeted customers of all ages 21 and over. While a large percentage were college students over 21, the pub attracted a good many 30, 40, 50, and 60 year olds. Because Marquette, Michigan, was a college town, it had a good supply of people willing to provide patronage to Blackrocks. It also had a large supply of professionals (medical community and university) who had enhanced disposable income.

Political/Legal: A micro-brewer's license costs $\$ 50$. This was required by the State of Michigan, and a Brewer's Notice $(\$ 1,000)$ bond was required by the federal government. Also, Blackrocks faced county regulations in terms of access to the building and parking and regulations set by the City of Marquette.

Blackrocks' industry environment can be best described using M. E. Porter's Five Forces Model (Porter, 1979) for Competitive Strategy:

Threat of Entrance: The capital investment to get into the retail pub business amounts to a fair amount of dollars in absolute terms, but in relative context, this type of business was inexpensive to enter. The Ore Dock entered the craft beer business after Blackrocks, and the Vierling preceded it. In general, entrance was not difficult.

Bargaining Power/Suppliers: Blackrocks purchased hops through a pre-purchased set price agreement with farmers in the Rock, Michigan area. They tended to use local hops because the price of other hops was substantially higher. In the purchase of hops there was balanced power between the farmer and Blackrocks. In regard to grains and most of the other products, a national or world price prevailed. The futures market set the price for these items. Therefore, Blackrocks was a price taker.

Bargaining Power/Buyers: For the primary market, demand for beer was relatively inelastic. Twentyone year olds were willing to pay to get the beer they wanted. Also, Blackrocks was on the bottom end of pricing compared to their major competitors. Buyers had lots of power.

Substitutes: The primary substitute for Blackrocks craft beer was hard liquor, wine, and wine coolers. If someone wanted to get high or drunk, a product was available to do so.

Competitive Rivalry: There was competitive rivalry between the Vierling, Ore Dock, and Blackrocks, but Blackrocks was in general a lower priced beer. Each company knew the other was in town.

Complementors: The law allowing the drinking of alcohol beverages at 21 was a major complementor to Blackrocks' business. Also, the university and its 2,000-3,000 students who were 21 and older were a ready market for Blackrocks. The State of Michigan and the federal government's licenses and bonding policies facilitated the existence of Blackrocks. As of 2013, the United States was a long ways away from moving toward prohibition.

Blackrocks' operating environment can be described as follows:

Competitors: The primary competitors were the Vierling and the Ore Dock.

Customers: The citizenry of the City of Marquette and the transient students of the university were the primary customer base as of 2013. Blackrocks had received a warm welcome from these customers since it opened. There was a good relationship between the company and its customers.

Credit: Blackrocks had a banking relationship with a local bank in Marquette, Michigan. The company had been successful to date. The business had a good working relationship with this bank.

Labor: There seemed to be an adequate supply of labor both in terms of price and technological qualifications. The company management did realize, however, that investments in further training could expand the technological knowledge of its brewers. This was also true of top management. 
b. What is (describe) the internal environment of the firm? The internal environment of the firm is best expressed by Hitt, Ireland, and Hoskisson (2001). Their framework is presented in Figure 7.

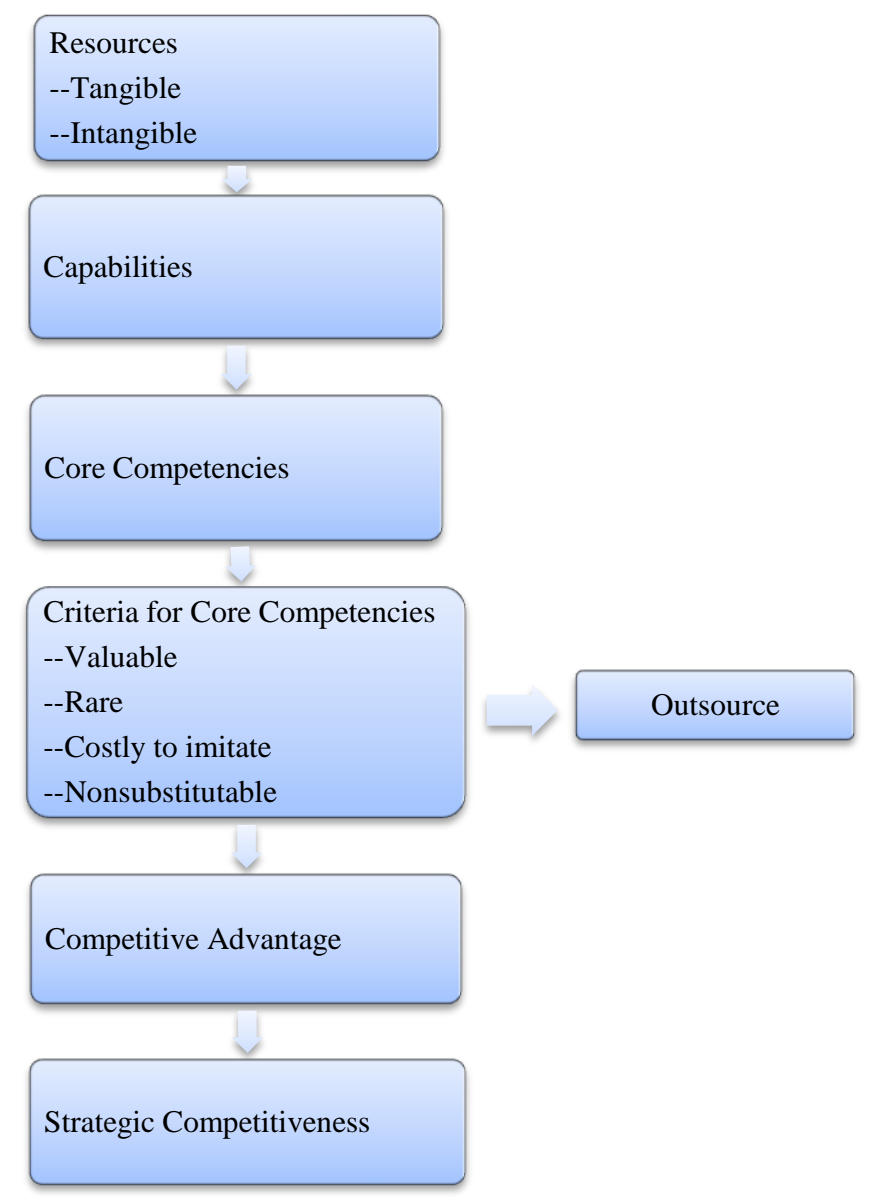

Figure 7: Components of Internal Analysis Source: Adapted from Hitt, Ireland, \& Hoskisson, 2001

Tangible resources: Blackrocks had their retail establishment at 424 N. Third Street, Marquette, Michigan. This location also held the brewing equipment. They had purchased an old Coca-Cola building for additional brewing capacity.

Intangible resources: Andy Langlois and David Manson had about 18 years of experience in business as sales persons and in managerial roles. Andy and David were friends and seemed to get along well with each other. They were informally co-CEOs. Andrew Reeves was the head brewer and Chris Chutte was a bartender and a brewer.

c. What are the capabilities and core competencies of the firm?

Capabilities: According to Hitt, Ireland, and Hoskisson (2001), "capabilities are the firm's capacity to develop resources that have purposely been integrated to achieve a desired end state" (p. 108). These capabilities develop over time and represent the complex interaction of tangible and intangible (human) resources. Most of these capabilities are housed in the people of an organization. The way people interact, for example, can create capabilities. It is the people who are working with other people or people working with non-human resources that create capabilities. Capabilities are what companies do well. They are not facts. Instead, they are things companies do. Common examples include research and development, marketing, logistics, and accounting. 
The following represent the capabilities of Blackrocks:

- Retail craft beer marketing: In the $2 \frac{1}{2}$ years Blackrocks had been in business, they had developed a successful business model. Their "fun and good times" and "top-quality craft beer" were in demand from a customer perspective. They had built a lasting relationship with customers. Whether it was because of pumpkin carving, beer mugs, or just top-quality craft beer, they had created an environment attractive to repeat purchase.

- Dedicated top management: Andy and David devoted 65+ hours a week in the business. Their everyday presence was an integral part of the business's success. They tended to think alike and had good communication skills.

Core competencies: The concept of core competencies was first described by Prahalad and Hamel (1990) in their HBR article entitled, "Core Competencies of the Firm." The term, core competencies, varies by author. Hill and Jones (2007), for example, in their Strategic Management text use the phrase, distinctive competencies (p. 77). Basically, capabilities that meet four criteria (rare, valuable, costly to imitate, and non-substitutable) become core competencies of the firm and were its strengths. If capabilities of a firm are what it does well, then core competencies are the things they do very well.

Blackrocks had two core competencies. Both retail craft beer marketing and a dedicated top management were core competencies or strengths of Blackrocks.

d. What are (describe) Blackrocks' strengths, weaknesses, opportunities, and threats?

Strengths: from above

- Retail craft beer marketing

- Dedicated top management

Weaknesses: these are the internal things the company does not do well.

- No job descriptions

- No formal reporting lines

- Weak planning and no advice and counsel

Opportunities

- A branded craft beer for Blackrocks?

- Wholesaling of a branded beer?

- Growth in market share?

Threats

- The general demand for craft beer (Marquette, Michigan)

- Competition

$\checkmark$ Vierling

$\checkmark$ Ore Dock

$\checkmark \quad$ Retail craft beer (mostly bottled)

$\checkmark$ Bottled/canned beer (in general)

3. What are (describe) the strengths/opportunities (SO) strategies, weaknesses/opportunities (WO) strategies, strengths/threats (ST) strategies, weaknesses/threats (WT) strategies for Blackrocks?

\section{SWOT Matrix}

The analytical tool of the SWOT Matrix (David, 2004) evolves from the Tows Matrix (Weihrich, 1982). This is an important matching tool that helps managers develop four types of strategies: SO 
(strengths/opportunities) strategy, WO (weaknesses/opportunities) strategy, ST (strengths/threats) strategy, and WT (weaknesses/threats) strategy (see Table 1). For the SWOT Matrix applied to Blackrocks for the year 2013, see Table 2. The SWOT Matrix helps develop the appropriate strategies that can be employed. As shown in Table 2, seven strategies seem to fall out of the SWOT Matrix for Blackrocks.

Table 1: The SWOT Matrix Structure

\begin{tabular}{|c|c|c|}
\hline & $\begin{array}{ll} & \text { Strengths }-\mathbf{S} \\
1 . & \\
2 . & \\
3 . & \\
4 . & \end{array}$ & $\begin{array}{l}\text { Weaknesses }-\mathbf{W} \\
1 . \\
2 . \\
3 . \\
4 .\end{array}$ \\
\hline $\begin{array}{ll} & \text { Opportunities }-\mathbf{O} \\
1 . & \\
2 . & \\
3 . & \\
4 . & \end{array}$ & $\begin{array}{l}\text { SO Strategies } \\
\text { Use strength to take advantage of } \\
\text { opportunities }\end{array}$ & $\begin{array}{l}\text { WO Strategies } \\
\text { Overcome weaknesses by taking } \\
\text { advantage of opportunities }\end{array}$ \\
\hline Threats - T & $\begin{array}{c}\text { ST Strategies } \\
\text { Use strengths to avoid threats }\end{array}$ & $\begin{array}{c}\text { WT Strategies } \\
\text { Minimize weaknesses and avoid threats }\end{array}$ \\
\hline
\end{tabular}

Source: David, 2004, p. 204

Table 2: The SWOT Matrix Structure for Blackrocks, February 2013

\begin{tabular}{|c|c|c|}
\hline & \begin{tabular}{l}
$\quad$ Strengths \\
\multicolumn{1}{c}{ 1. retail craft beer marketing } \\
2. dedicated, hardworking top \\
management
\end{tabular} & $\begin{array}{l}\text { Weaknesses } \\
\text { 1. no job descriptions } \\
\text { 2. no formal reporting lines } \\
\text { 3. weak planning and no advice and counsel }\end{array}$ \\
\hline \begin{tabular}{l}
\multicolumn{1}{c}{ Opportunities } \\
1. a "branded" craft beer from \\
Blackrocks? \\
2. wholesaling a "branded" beer \\
3. growth in market share
\end{tabular} & $\begin{array}{l}\text { SO Strategies } \\
\text { 1. S1,O1 - investigate the } \\
\text { development of a "brand" that } \\
\text { represents the brewer Blackrocks } \\
\text { 2. S2, O2 - Andy and David needed } \\
\text { to investigate the feasibility of } \\
\text { finding a wholesaler to take on their } \\
\text { brand or wholesale it themselves. }\end{array}$ & $\begin{array}{l}\text { WO Strategies } \\
\text { 1. W1,O3 - write formal job descriptions for } \\
\text { all employees - full- and part-time } \\
\text { 2. W2,O3 - create a formal organizational } \\
\text { chart; formally recognize the co-CEO } \\
\text { relationship } \\
\text { 3. W3,O3 - develop a 3-year strategic plan } \\
\text { 4. W3, O4 - create a business advisory council } \\
\text { for top management. (4 meetings per year) }\end{array}$ \\
\hline \begin{tabular}{l}
\multicolumn{1}{c}{ Threats } \\
1. general demand for beer \\
2. competition \\
A. Vierling \\
B. Ore Dock \\
C. Retail \\
3. specialty beer \\
4. bottled and canned beer in \\
general
\end{tabular} & $\begin{array}{l}\text { ST Strategies } \\
\text { 1. S2, T2 - on a yearly basis monitor } \\
\text { the external and internal environment } \\
\text { of the firm. }\end{array}$ & WT Strategies \\
\hline
\end{tabular}

Strategy One: S1/O1: Investigate the development of a brand that represents "Blackrocks." Blackrocks prides itself on the idea of variety - new and different beer every few weeks. This policy leaves it up to the buyers to decide which beer they like best. Even though mass customization and lean production have come a long way, it is not feasible to produce and bottle 10 or 12 beers for a company like Blackrocks. Therefore, Blackrocks must choose the one or two beer that best represent the brewer "Blackrocks."

Planning for the production of a given beer requires the design of a label (Blackrocks logo, etc.) and a bottle or can. It also requires the coordination of production with demand. The decision to produce a beer of choice requires a company to pay close attention to production capacity. 
What beer to make is an integral part of this strategy. Blackrocks could use one of its strengths, "retail craft beer marketing," to develop the beer of choice. For example, for 3 or 4 months Blackrocks could have a contest - let the customer decide which beer is best. What should Blackrocks represent and what should the beer be named were important questions to answer.

Attention must be given to the production process. Most likely, production runs at first or even in the long run would be filled by "outsourcing." If absolute control were required, this strategy would be strategic in nature and require a significant capital investment in production, bottling facilities, and marketing. This strategy would be investigatory at this point.

Strategy Two: S2/O2: Investigate the feasibility of a wholesaler to take on this brand. At first this would require a local or regional wholesaler who would take on the brewer Blackrocks. Issues like the wholesale and retail price point for the beer would be important. The reach of the brand named Blackrocks would also be important. This discussion would require some work. It may be that the brand would have to be established locally at first. The brand would always be part of Blackrocks' venue. The market needs to identify the "brand." That is, its taste, its flavor, and its aroma as representing the brewer, Blackrocks. This strategy needs to be carefully planned regarding production and distribution as well as retail pricing points for the beer. This strategy also is investigatory in nature.

Strategy Three: S2/T2: On a yearly basis, produce a report that describes the external and internal environment of the firm. Every two years, review the company's SWOT (strengths, weaknesses, opportunities, and threats). Make sure it is constantly up to date. Given the structure of Blackrocks at this time, it should be done by the company's co-owners. This strategy would require very little in the form of capital investment.

Strategy Four: W1/O3: Write formal job descriptions for all employees - full- and part-time. Andy and David would do this best. It would be interesting for each of them to do it on their own and then compare the descriptions. Do the lists agree or are there differences? If the latter prevails, then the owners should work out the details and present the final form to the employees. Andy and David should also have formal written job descriptions.

They must understand that they are co-CEOs. This is a somewhat uncommon form of business leadership, but it is an acceptable form used in businesses across the United States today. If job activity is allocated appropriately between the two business leaders, it can work well. To know who will handle what is important because it leaves nothing to "fall through the cracks." It also eliminates the problem of two bosses for subordinates. This strategy did not require significant capital investment.

Strategy Five: W2/O3: Create a formal organizational chart. For a company of this size, this strategy is easily executed. Andy and David should create the form first and consolidate it with their respective ideas folded together. They needed to work out any conflicts.

In the long run, the organizational chart should be shared with employees. Who handles finances and accounting? How is marketing executed? Where does production fit into the business? Who reports to whom? No capital was required to execute this strategy.

Strategy Six: W3/O3: Develop a 3-year (ongoing) strategic plan for the business. This is not a capital intensive strategy, but it would require Andy and David to look at their mission statement and determine where they want to be in the next 3 years. They need to set out their goals which, when achieved, will meet their mission.

Questions should be considered such as what return on invested capital do we want in 2013, 2014, and 2015? What do we have to do to achieve these numbers? How much do we need to reinvest in the business each year to keep it competitive? Appendix 1 represents a broad outline for achieving an ongoing 3-year business plan. 
Strategy Seven: W3/O4: Create a business advisory board. Blackrocks is at a critical point in their business. Its products have had consumer acceptance. The company to date is profitable and each major owner is receiving a salary.

A group of dedicated business people with the right kind of experience could aid Andy and David immensely. SCORE might be a source for some of these people. Andy and David have knowledge of the business so they might be able to identify other individuals. What's important is to find four or five dedicated people who have solid experience running successful and profitable businesses. The key question would be to get them to volunteer their time at first, and in the long run, provide a nominal stipend for their advice. The advisory board should rotate on a three- or four-year term in the long run. This strategy represents a nominal capital investment.

\section{EPILOGUE}

Andy and David produced their first retail beer for sale in September 2013. 


\section{APPENDIX 1}

\section{Ongoing Business Plan \\ (Mariott \& Glackin, 2010, p. 32)}

A business plan helps explain your business idea and how that idea will be implemented. Your business plan will help you determine whether your business is viable before the business start-up, and it forces you to realistically analyze opportunities and markets before you secure the necessary capital.

The common elements to a business plan are as follows:

- $\quad$ Mission, vision, and culture

- Company description

- $\quad$ Opportunity analysis and research

- $\quad$ Marketing strategy and plan

- $\quad$ Management and operations

- $\quad$ Financial analysis and projections

- $\quad$ Funding request and exit strategy 